\title{
PENGARUH KONSUMSI SUSU TEMPE TERHADAP KADAR HAEMOGLOBIN PADA IBU HAMIL TRIMESTER III
}

\section{NOVITA BR GINTING MUNTHE ${ }^{1}$, G.F GUSTINA SIREGAR ${ }^{2}$, NURSYIDAH ${ }^{3}$, ISKANDAR MARKUS SEMBIRING ${ }^{4}$}

\author{
${ }^{1,4}$ Institut Kesehatan Medistra Lubuk Pakam \\ 2,3Institut Kesehatan Deli Husada Deli Tua
}

\section{Jl. Sudirman No.38 Lubuk Pakam Kab. Deli Serdang-Sumatera Utara e-mail : novitagintingmunthe89@gmail.com}

\begin{abstract}
Anemia in pregnancy can adversely affect the mother, especially during pregnancy, childbirth and the puerperium. The high prevalence of anemia has negative consequences such as disturbances and inhibition of growth, both body and brain cells, lack of hemoglobin in the blood resulting in a lack of oxygen being under/transferred to body cells and to the brain. Pregnant women who suffer from anemia have the possibility to experience post partum bleeding. Tempe has higher quality and nutritional value. The fermentation process in tempe will activate the phytase enzyme which can break down phytic acid. With the breakdown of phytic acid, minerals such as iron, calcium, magnesium and zinc become more available for use by the body. This study aims to determine the effect of tempeh milk consumption on increasing hemoglobin levels in pregnant women in the independent practice of midwife Zuhrah, Samudera District, North Aceh District in 2021. The method in this study is a quasiexperimental study, the design used is one group pre-posttest design. By using the Wilcoxon test. The results showed that the average $\mathrm{HB}$ level in pregnant women before consuming tempeh milk was $9 \mathrm{gr} \%$ and $12 \mathrm{gr} \%$ after consuming tempeh milk. The results showed that the positive ranks value was 8.50 , so it could be concluded that there was an increase in hemoglobin levels after being given tempeh milk compared to before being given tempeh milk, so the hypothesis decision was that there was a significant difference in the pre-postest respondents who were given tempeh milk. So it can be concluded that $\mathrm{HO}$ is rejected and $\mathrm{Ha}$ is accepted. It is hoped that health workers can provide information to all pregnant women so that they can consume tempe as a daily food ingredient.
\end{abstract}

Keywords: Anemia, pregnant women, tempeh milk.

\section{PENDAhUlUAN}

Anemia merupakan suatu kondisi terjadinya kekurangan pada sel darah merah. Apabila sel darah merah berkurang, maka asupan oksigen dan aliran darah ke otak juga semakin berkurang. Selain itu, sel darah merah juga mengandung haemoglobin yang fungsinya mengalirkan oksigen ke semua jaringan tubuh. Apabila hal tersebut terjadi, seseorang dapat merasakan pusing, bahkan pingsan. 
Jurnal Kesehatan Masyarakat \& Gizi, e-ISSN: 2655-0849

Vol. 3 No.2 Edisi November 2020 - April 2021

https://ejournal.medistra.ac.id/index.php/JKG

Received: 13 April 2021 :: Accepted: 24 April 2021 :: Published: 27 April 2021

Dampak anemia di antaranya kelelahan, badan terasa lemah, dan penurunan produktivitas kerja. Sementara itu, penyebab anemia pada ibu yang sedang hamil adalah kurangnya zat besi (Fe) dan asam folat, serta terjadinya perdarahan yang akut (Astriana, 2017).

Efek dari kejadian anemia selama kehamilan terhadap ibu mempengaruhi keadaan Ibu terutama saat menjalani kehamilan, proses persalinan dan masa nifas atau postpartum. Selain itu, Tingginya Prevalensi anemia yang tinggi berakibat buruk pada janin, seperti terganggu dan adanya hambatan pada pertumbuhan sel tubuh maupun otak, Kadar HB yang rendah dapat mengakibatkan kurangnya aliran oksigen yang dibawa/ditransfer ke bagian sel tubuh dan otak (Purwandari, dkk, 2016).

Berdasarkan hasil dari Riset Kesehatan Dasar (RisKesDas) 2018, ibu hamil yang terkena anemia di Indonesia mencapai sebanyak 48,9\%. Hal tersebut menunjukkan adanya peningkatan anemia pada Ibu hamil dibandingkan tahun 2013 sebesar 37,1 \%. Prevalensi Ibu hamil yang mengalami anemia sesuai usia, pada usia 15-24 tahun $(84,6 \%)$, usia $25-34$ tahun $(33,7 \%)$, usia 35- 44 (33,6\%), usia 45- 45 (24\%) (Riskesdas, 2018).

Diketahui lima penyebab kematian terbesar ibu yaitu perdarahan, tekanan darah tinggi (hipertensi), partus lama dan abortus. Anemia pada Ibu hamil dapat meningkatkan terjadinya komplikasi pada saat hamil dan bersalin seperti abortus, bayi lahir prematur, partus lama, atonia uteri, sub involusi pada masa nifas dan terjadinya infeksi. Oleh karena terjadinya anemia pada Ibu hamil dapat meningkatkan kejadian mortalitas. (Wigunantiningsih, dkk, 2017).

Ketidakpatuhan Ibu hamil dalam mengkonsumsi tablet zat besi juga meningkatkan kejadian anemia. Hal tersebut terjadi karena efek samping dari konsumsi tablet zat besi tersebut membuat Ibu hamil mual dan muntah, fecal impaction dab beberapa ibu bosan padahal kita ketahui bahwa pemerintah telah membuat program suplementasi besi sebanyak 90 tablet setiap hari selama Trimester III dengan memberikannya secara gratis kepada ibu hamil yang mana tingkat keberhasilan yang diharapkan cukup tinggi untuk mencegah kejadian anemia (Novianti, dkk., 2019). Dengan adanya keluhan tersebut, maka peneliti memberikan solusi pemenuhan zat besi pada ibu hamil dengan terapi non farmakologi.

Terapi non farmakologi yaitu salah satu cara untuk mencegah terjadinya anemia khususnya pada kehamilan di trimester ketiga dengan cara memberikan susu tempe. Tempe mempunyai nilai asupan gizi yang lebih tinggi dibandingkan kedelai murni. Proses fermentasi pada tempe akan mengaktifkan enzim fitase yang dapat menguraikan asam fitat menjadi fosfor dan isotol. Dengan demikian asam fitat dan beberapa mineral tertentu seperti besi, magnesium, kalsium, dan seng yang dapat dimanfaatkan oleh seluruh organ tubuh. Enzim ini juga berperan meningkatkan absorbsi mineral besi di dalam darah (Novianti,dkk, 2019).

Tempe adalah makanan tradisional hasil dari suatu fermentasi biji kedelai yang kaya serat pangan, zat besi, kalsium, dan vitamin B. Fermentasi menggunakan Rhizopus oryzae, Rhizopus oligosporus, Rhizopus stolonifer, dan jenis kapang Rhizopus lainnya. Dalam proses fermentasi tersebut terjadi suatu hidrolisis dari senyawa kompleks menjadi sederhana yang baik untuk dicerna (PUSIDO, 2012).

Penelitian ini bertujuan untuk mengetahui pengaruh konsumsi susu tempe terhadap peningkatan kadar 
haemoglobin pada Ibu Hamil trimester III.

\section{METODE PENELITIAN}

\section{Jenis dan Desain Penelitian}

Metode penelitian pada penelitian ini adalah quasi eksperimen dengan rancangan yang digunakan adalah one group pre-post test design. Dengan meggunakan uji Wilcoxon. Dalam rancangan ini kelompok eksperimen dinilai dari hasil sebelum dan sesudah diberikan intervensi.

Teknik pengumpulan data dengan menggunakan data primer yang bersumber dari hasil pengumpulan data secara langsung melalui pengukuran kadar HB ibu hamil yang memiliki anemia pada trimester III sebelum dan sesudah diberikan susu tempe sebanyak $250 \mathrm{ml}$ dengan frekuensi 2 kali pehari selama 7 hari.

\section{Populasi Penelitian}

Populasi dalam penelitian ini adalah ibu hamil Trimester III sejak 3 bulan terakhir yang sebanyak 110 orang di Praktik Mandiri Bidan Zuhrah di Kecamatan Samudera Kabupaten Aceh Utara.

\section{Sampel Penelitian}

Teknik pengambilan sampel dalam penelitian ini adalah teknik non probality sampling dengan metode purposive sampling yaitu cara penarikan sampel yang dilakukan dengan memilih subjek berdasarkan karakteristik tertentu yang dianggap berhubungan dengan karakteristik pada populasi yang sebelumnya sudah dapat diketahui. Penentuan sampel menggunakan kriteria pemilihan sampel, yaitu kriteria inklusi dan eksklusi:

Kriteria inklusi adalah diteliti (Notoatmodjo, 2013), antara lain:

a. Ibu hamil Trimester III yang mengalami anemia ringan b. Ibu yang tidak pernah mengkonsumsi susu tempe

c. Bersedia menjadi responden. Kriteria eksklusi, antara lain:

a. Ibu hamil Trimester III yang disertai komplikasi dalam kehamilan

b. Tidak berada di tempat saat pengambilan data dilakukan.

Sampel yang diteliti sebanyak 16 orang.

\section{Lokasi dan Waktu Penelitian}

Penelitian ini dilaksanakan pada bulan Oktober 2020 - Maret 2021 di Praktik Mandiri Bidan (PMB) Zuhrah Kecamatan Samudera Kabupaten Aceh Utara.

\section{Instrumen Penelitian}

Instrumen adalah alat untuk mengumpulkan setiap data di suatu penelitian, instrumen yang digunkan dalam penelitian ini adalah, lembar observasi, dan alat HB quick check.

\section{Analisis Data}

\section{a. Analisis Univariat}

Analisisa ini dilakukan terhadap setiap variabel dari hasil penelitian pada umumnya hasil analisa ini berupa distribusi dan persentase dari masing masing variabel (Notoatmodjo, 2013). Analisa univariat dalam penelitian ini dilakukan untuk mengidentifikasi distribusi frekuensi peningkatan kadar HB pada ibu hamil kelompok perlakuan dan kontrol diberikan susu tempe.

\section{b. Analisa Bivariat}

Analisa bivariat dilakukan terhadap dua variable yang diduga berkorelasi (Masturoh, 2018). Analisis ini untuk mencari pengaruh variabel bebas (pemberian susu tempe) terhadap variabel terikat (peningkatan kadar haemoglobin). Hasil penelitian dianalisis dengan menggunakan uji quasi eksperimen one group dengan uji willcoxon yang digunakan untuk 
Jurnal Kesehatan Masyarakat \& Gizi, e-ISSN: 2655-0849

Vol. 3 No.2 Edisi November 2020 - April 2021

https://ejournal.medistra.ac.id/index.php/JKG

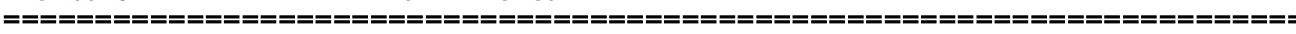

Received: 13 April 2021 :: Accepted: 24 April 2021 :: Published: 27 April 2021

membandingkan hasil observasi kelompok sebelum dan sesudah dilakukan intervensi.

\section{HASIL}

Tabel 1. Distribusi Rata - Rata Kadar Haemoglobin Pada Responden Sebelum Dan Sesudah Pemberian Susu Tempe

\begin{tabular}{lccc}
\hline Kadar HB & $\mathrm{N}$ & Mean & $\begin{array}{c}\text { Std. } \\
\text { Deviation }\end{array}$ \\
\hline Pretest & 16 & 9.0325 & .03493 \\
Posttest & 16 & 12.2163 & .39009 \\
\hline
\end{tabular}

Berdasarkan hasil analisa dari tabel 1 diketahui bahwa rata-rata kadar Haemoglobin pada responden penelitian sebelum diberikan susu tempe yaitu 9 gr\%, sedangkan rata-rata kadar Haemoglobin pada responden penelitian setelah diberikan susu tempe yaitu 12,2 gr\%. Sehingga dapat disimpulkan bahwa terdapat peningkatan kadar Haemoglobin pada responden sebelum dan sesudah pemberian susu tempe.

Tabel 2. Pengaruh Konsumsi Susu

Tempe Terhadap Peningkatan Kadar Haemoglobin Ibu Hamil Trimester III Di

Praktik Mandiri Bidan Zuhrah di Kecamatan Samudera Kabupaten Aceh

\begin{tabular}{|c|c|c|c|c|}
\hline \multicolumn{5}{|c|}{ Utara } \\
\hline \multicolumn{2}{|c|}{$\begin{array}{c}\text { Kadar } \\
\text { Haemoglobin }\end{array}$} & $\mathrm{N}$ & $\begin{array}{l}\text { Mean } \\
\text { Rank }\end{array}$ & $\begin{array}{l}\text { Sum } \\
\text { of }\end{array}$ \\
\hline \multirow{4}{*}{$\begin{array}{c}\text { Pretest } \\
- \\
\text { Posttest }\end{array}$} & $\begin{array}{c}\text { Negative } \\
\text { Ranks }\end{array}$ & $0^{a}$ & .00 & .00 \\
\hline & $\begin{array}{c}\text { Positive } \\
\text { Ranks }\end{array}$ & $16^{b}$ & 8.50 & 136.00 \\
\hline & Ties & $0^{c}$ & & \\
\hline & Total & 16 & & \\
\hline
\end{tabular}

Berdasarkan tabel 2 terlihat hasil uji statistik pada peningkatan kadar haemoglobin pada responden dimana diketahui bahwa :

a. Negatif ranks artinya sampel dengan nilai kelompok kedua (posttest) lebih rendah dari nilai kelompok pertama (pretest). Dalam penelitian ini diketahui bahwa nilai negatif rank bernilai 0 artinya kadar haemoglobin pada responden tidak mengalami penurun setelah diberikan susu tempe.

b. Positive ranks adalah sampel dengan nilai posttest lebih tinggi dari nilai pretest. Dalam peneltian ini nilai positif ranks yaitu 8.50 sehingga dapat diasumsikan bahwa setelah diberikan susu tempe ada peningkatan kadar haemoglobin dibandingkan sebekum diberikan susu tempe

c. Ties merupakan nilai posttest yang sama besarnya dengan nilai pretest, simbol $\mathrm{N}$ menunjukkan jumlahnya, mean rank adalah peringkat rata ratanya dan sum of ranks adalah jumlah peringkatnya.

\section{PEMBAHASAN}

Anemia dalam kehamilan adalah suatu keadaan ibu hamil dengan kadar haemoglobin $(\mathrm{Hb})$ kurang dari $11 \mathrm{gr} \%$ pada trimester I dan III sedangkan pada trimester II kadar haemoglobin kurang dari 10,5 gr\%. Oleh karena itu, kejadian anemia pada Ibu hamil harus dapat dicegah dan diatasi serta membutuhkan perhatian serius dari tenaga kesehatan seperti Bidan dan Dokter maupun Keluarga. Risiko kematian pada Ibu hamil dengan anemia sebesar 3,6 kali dibandingkan dengan Ibu yang tidak anemia dan juga mempunyai persentase yang tinggi (50 - $70 \%$ ) menyebabkan mortalitas pada Ibu hamil (Aryanti, dkk., 2013).

Faktor resiko kejadian anemia paling utama adalah umur. Umur ibu hamil berhubungan erat dengan alat alat reproduksi wanita. Umur reproduksi ideal adalah 20 - 35 tahun. Ibu hamil yang berusia $<20$ tahun dan $>35$ tahun dapat beresiko mengalami anemia. Hal ini karena pada usia < 20 tahun, secara biologis, emosi ibu hamil belum stabil 
Jurnal Kesehatan Masyarakat \& Gizi, e-ISSN: 2655-0849

Vol. 3 No.2 Edisi November 2020 - April 2021

https://ejournal.medistra.ac.id/index.php/JKG

Received: 13 April 2021 :: Accepted: 24 April 2021 :: Published: 27 April 2021

sehingga kurang memperhatikan pemenuhan kebutuhan zat gizi bagi dirinya selama kehamilan. Di sisi lain, ibu hamil yang berusia $>35$ tahun, daya tahan tubuhnya semakin menurun dan rentan terhadap penyakit (Pratiwi \& Fatimah, 2019).

Tempe sangat berkhasiat mencegah terjadinya anemia dan osteoporosis, sebab kodrat setiap wanita mengalami haid, dan ketika menikah harapannya hamil serta menyusui bayinya. Penyakit anemia ini sering terjadi ketika wanita tidak teratur makan, takut kelihatan gemuk, malas makan, sehingga terjadi penurunan sel darah merah di tubuh wanita tersebut. Peran dari konsumsi Tempe adalah pemasok mineral, zat besi, vitamin B12, serta sangat berfungsi membentuk sel darah merah dan menurunkan kolesterol dalam darah. Senyawa yang terdapat di dalam tembe adalah protein, serat, niasin, asam lemak Polyunsaturated Fatty Acid (PUFA), dan kalsium yang dapat menurunkan kadar kolesterol jahat di daam tubuh.

Berdasarkan hasil penelitian diketahui bahwa nilai negatif rank bernilai 0 artinya kadar haemoglobin pada responden tidak mengalami penurun setelah diberikan susu tempe sedangkan nilai positif ranks sebesar 8.50 sehingga dapat diasumsikan bahwa setelah diberikan susu tempe ada peningkatan kadar haemoglobin dibandingkan sebekum diberikan susu tempe

Diketahui pula bahwa rata-rata kadar Haemoglobin pada responden penelitian sebelum diberikan susu tempe yaitu $9 \mathrm{gr} \%$, sedangkan rata-rata kadar Haemoglobin pada responden penelitian setelah diberikan susu tempe yaitu 12,2 gr\% yang menunjukkan bahwa terdapat peningkatan kadar Haemoglobin pada responden sebelum dan sesudah pemberian susu tempe.
Hasil penelitian ini sejalan dengan penelitian Yuniwati, dkk (2014), bahwa ada pengaruh pemberian susu tempe terhadap peningkatan kadar haemoglobin ibu hamil trimester III dari hasil penelitiannya menunjukkan bahwa rerata kadar HB ibu hamil trimester sebelum diberikan susu tempe $11.41 \mathrm{gr} \%$ namun setelah diberikan susu tempe selama beberapa hari mengalami peningkatan menjadi $12.50 \mathrm{gr} \%$.

Hasil penelitian ini didukung juga oleh penelitian yang dilakukan oleh Febrianti (2011), bahwa ada pengaruh yang signifikan suplementasi tempe kedelai murni terhadap peningkatan kadar HB pada tikus putih dengan anemia.

\section{KESIMPULAN}

Rerata kadar HB pada responden penelitian sebelum diberikan susu tempe yaitu 9gr\%, sedangkan rerata kadar HB pada responden penelitian setelah diberikan susu tempe yaitu $12,2 \mathrm{gr} \%$. Yang berarti ada pengaruh konsumsi susu tempe terhadap peningkatan kadar haemoglobin pada ibu hamil trimester III di Praktik Mandiri Bidan Zuhrah HH Kecamatan Samudera Kabupaten Aceh Utara.

\section{DAFTAR PUSTAKA}

Aryanti Wardiah, Sumini Setiawati, Riyani, Riska Wandiri, Lidya Aryanti. (2013) Faktor - faktor yang mempengaruhi kejadian anemia pada ibu hamil di wilayah kerja Puskesmas Sekampung Kabupaten Lampung Timur tahun 2013. Bandar Lampung: PSIK Universitas Malahayati.

Astriana, W. (2017). Kejadian anemia pada ibu hamil ditinjau dari paritas dan usia. Aisyah : Jurnal Ilmu Kesehatan 2(2) 2017, 123-230.

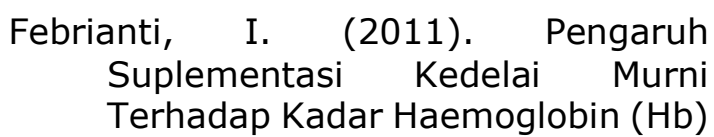


Darah Pada Tikus Putih (Rattus Novergicus). Universitas Negeri Semarang E.lib

Masturoh, I., Anggita. (2018). Metodologi Penelitian Kesehatan Edisi 1. Jakarta: Kemenkes RI.

Notoatmodjo, S. (2013). Metodologi Penelitian Kesehatan. Jakarta: Rineka Cipta.

Novianti., Asmariyah., \& Suriyati .(2019). Pengaruh Pemberian Susu Tempe Terhadap Kadar Haemoglobin Pada Ibu Hamil TM III Di Kota Bengkulu. Jurnal Maternal. Vol 7 No. 1. April 2019.

Pratiwi, A. M. \& Fatimah. (2019) Patologi Kehamilan. Yogyakarta: Pustaka Baru.

Purwandari, A., Lumy, F., \& Polak, F. (2016). Faktor - Faktor Yang Berhubungan Dengan Kejadian Anemia. Jurnal Ilmiah Bidan. Poltekes Kemenkes Manado, Vol 4 No. 1. Januari - Juni 2016.

PUSIDO. (2012). Tempe: Persembahan Indonesia Untuk Dunia. Jakarta : Badan Standarisasi Nasional.

Riskesdas. (2018). Hasil Utama Riskesdas 2018. Kementerian Kesehatan Badan Penelitian Dan Pengembangan Kesehatan. Jakarta : Kemenkes RI.

Wigunantiningsih, A., \& Fakhidah, L.N. (2017). Faktor - Faktor yang Mempengaruhi Kejadian Anemia Ibu Hamil Trimester III Pada Kunjungan ANC di Stikes Mitra Husada Karang Anyar. Jurnal Maternal Vol 2 No 2.

Yuniwati., Yorita. E., \& Lubis., Y. (2014). Pengaruh Pemberian Susu Tempe Terhadap Kadar Haemoglobin Pada Ibu Hamil TM III, Jurnal Media Kesehatan. Vol. 8 No. 2. 